\title{
The economics of natural disasters in a developing country: The case of Vietnam
}

\author{
Ilan Noy ${ }^{\mathrm{a}, *}$, Tam Bang $\mathrm{Vu}^{\mathrm{b}}$ \\ a Department of Economics, University of Hawaii-Manoa, 2424 Maile Way, Honolulu, HI 96734, USA \\ ${ }^{\mathrm{b}}$ College of Business and of Economics, University of Hawaii-Hilo, USA
}

\section{A R T I C L E I N F O}

Article history:

Received 14 May 2009

Received in revised form 17 January 2010

Accepted 8 March 2010

\section{JEL classification:}

O40, Q54

Keywords:

Vietnam

Natural disaster

Growth

Exogenous shocks

\begin{abstract}
A B S T R A C T
We examine the impact of natural disasters on annual output growth in Vietnam. Using provincial data for primary and secondary industries, we employ the Blundell-Bond General Method of Moments procedure to estimate the impact of disasters on the macroeconomy. We show that more lethal disasters result in lower output growth but that disasters that destroy more property and capital actually appear to boost the economy in the short-run. This is consistent with the 'investment-producing destruction' hypothesis that we outline. However, we find that disasters have a different macroeconomic impact in different geographical regions; these differences are potentially related to the ability to generate transfers from the Vietnamese central government.
\end{abstract}

(c) 2010 Elsevier Inc. All rights reserved.

\section{Introduction}

Natural disasters have always resulted in significant economic and human loss. Major recent catastrophic events-such as the December 2004 tsunami in the Indian Ocean, the Pakistani Kashmir earthquake of October 2005 and cyclone Nargis that hit Myanmar in May 2008-have brought the human and material cost of these disasters to the forefront of public attention worldwide, and especially in Asia. Natural disasters now also figure prominently in numerous policy debates, especially in relation to global warming and the attendant changes in the patterns of climatic events that are predicted to accompany it. ${ }^{1}$

Research in both the social and natural sciences has been devoted to increasing our ability to predict disasters, prepare for them and mitigate their direct costs. Curiously, few economists participate in this research; though one existing strand of economic research on the topic focuses on disasters ex ante; it examines how societies can better prepare themselves to the onset of disasters and what determines the direct damage they cause. We focus on the natural disasters' ex post impact on the macroeconomy. We measure and estimate the costs of these natural disasters in terms of forgone production, using a comprehensive provincial panel dataset for Vietnam. We critically examine several hypotheses regarding the determinants of these costs, and compare the economic costs of disasters across different geographical areas within Vietnam.

Several recent studies have found a positive correlation between the frequency of natural disasters and long-run economic growth and have interpreted that as evidence that disasters provide opportunities for reconstructing the capital

\footnotetext{
* Corresponding author. Tel.: +1 808956 7749; fax: +1 8089564347.

E-mail addresses: noy@hawaii.edu (I. Noy), tamv@hawaii.edu (T.B. Vu).

${ }^{1}$ Changing sea, land and air temperatures, rising sea levels, changing patterns of rain and snow and an unstable climate are all likely catalysts of future weather-related events. For now, there is apparently no evidence that geo-physical disasters may also be affected by global warming.
} 
Table 1

Descriptive statistics for disaster variables.

\begin{tabular}{|c|c|c|c|c|c|}
\hline Region & Obs. $^{a}$ & Killed $^{\mathrm{b}}$ & Affected $^{\mathrm{c}}$ & Damage $^{d}$ & Annual obs. ${ }^{e}$ \\
\hline Red River Delta & 63 & 0.11 & 44.25 & 3.08 & 1.34 \\
\hline Northeast & 76 & 0.15 & 49.21 & 4.33 & 1.43 \\
\hline Northwest & 56 & 0.13 & 45.32 & 5.13 & 1.62 \\
\hline North Central Coast & 125 & 0.29 & 127.54 & 11.85 & 2.21 \\
\hline South Central Coast & 108 & 0.28 & 114.73 & 10.04 & 3.65 \\
\hline Central highlands & 78 & 0.16 & 116.43 & 9.52 & 3.15 \\
\hline Southeast & 78 & 0.21 & 98.34 & 8.68 & 2.06 \\
\hline Mekong Delta & 68 & 0.19 & 84.86 & 7.54 & 1.87 \\
\hline Total & 732 & 0.20 & 75.52 & 5.58 & \\
\hline
\end{tabular}

For detailed description of variables and sources, see Section 3.1. All variables are from the EM-DAT database.

a Number of disaster observations per Vietnamese region.

b Number of people killed (mean per 10,000).

c Number of people affected (mean per 1000).

d Damage (mean\% of output).

e Number of events per year (mean).

stock to make it more productive - we term this the 'investment-producing destruction' hypothesis. ${ }^{2}$ We examine this hypothesis not by examining the long-run growth (since it is likely dependent on many unobservables) but rather whether the destruction indeed generates a period of renewed economic activity and investment in the short-run. We further define what conditions make these dynamics more likely.

We use a regional panel dataset rather than an international panel so that our results will not be muddied by doubts that other national events or macroeconomic dynamics (exchange rate fluctuations, terms of trade shocks, financial crises, etc.) may be biasing our results. Using regional data enables us to ignore any unobservable institutional characteristics. We focus on Vietnam for several reasons: Vietnam experiences frequent weather-related natural disasters; not unlike other coastal nations like the Philippines and Cambodia. The largest disaster in the 20th century in Vietnam, in terms of the number of people killed, was a storm in 1964 that killed about 7000 people while the top 10 disasters killed a cumulative 16,000 people. ${ }^{3}$ The frequency of disasters and the absence of very large events make results applicable to 'average' disasters and less susceptible to the impact of outliers. ${ }^{4}$ Furthermore, while disasters in Vietnam occur more frequently in the Central Coast area, they occur throughout the country, and thus enable identification of impacts using a regional panel data. Vietnam is useful as a case study for investigation into the economic consequences of disasters in developing countries as Vietnam is also a rapidly developing emerging market, with both a viable agricultural sector and a rapidly increasing manufacturing sector. As such, the identified economic impact will be of relevance to countries at various stages of industrialization. Our use of panel data from a single country also allows us to ignore any distinctive characteristics that are potentially unobservable but are identical in all regions within a single country.

Table 1 presents descriptive statistics on the disaster variables we use. The table presents, for the main eight Vietnamese geographical regions, the number of disasters and their frequency, the average deaths per disaster (as \% of provincial population), the number of people affected (as \% of provincial population) and the physical damage (as \% of provincial output). It is apparent that the coastal areas experience more frequent and harmful disasters. By most measures, the coastal disasters (typically storms and wave surges) are on average 2-3 times more damaging than disasters elsewhere; especially when compared to the Northern regions (the Red River Delta, the Northeast and Northwest). Overall, there are 732 disaster observations in our dataset.

Below, we describe the existing literature and highlight our contribution to it. We follow with a discussion of the data, methodology, and findings of this paper; and conclude by pointing out some policy implications of our findings.

\section{The economics of natural disasters in previous research}

We briefly describe previous research that is directly relevant to this paper. A more thorough survey is available in Cavallo and Noy (2009).

\footnotetext{
${ }^{2}$ Much of the literature calls these dynamics 'creative destruction;' but this concept deviates significantly from the Schumpeterian concept (see Schumpeter, 2008). In fact, a more accurate term for the Schumpeterian Capitalist dynamics of innovation that destroys obsolete firms would be 'destructive creation.' We choose to use the term 'investment-producing destruction' to emphasize its distinctness from the Schumpeterian connotation. Skidmore and Toya (2002) is the most widely cited work in this literature that supports this hypothesis - which they term 'creative destruction'; though some recent works dispute their findings (e.g., Cuaresma, Hlouskova, \& Obersteiner, 2008; Noy \& Nualsri, 2008).

${ }^{3}$ In terms of the number of people affected, the largest event was a 1980 storm that affected more than 9 million people. In terms of direct damages, the costliest storm occurred in 2006 and destroyed US\$ 624 million in property.

${ }^{4}$ In this paper, we are more interested in the small scale and repetitive disasters that buffet some developing countries rather than the very large and dramatic once-in-a-century events like the South-East-Asian Tsunami of 2004.
} 


\subsection{Output growth and disasters}

Economic research on natural disasters is only in its infancy with very few papers examining any facet of disaster phenomena. Two exceptions of well developed research strands are worth noting. There is a significant body of microdevelopment research which examines the ways in which mostly rural households prepare and deal with sudden unexpected income shocks and the households' ability to insure against them (e.g., Paxson, 1992). The second existing strand examines specific disaster events - such as hurricane Mitch in Honduras, the Kobe earthquake in Japan, and estimates some of the specific costs and consequences of those individual events (e.g., Benson and Clay, 2004; Coffman \& Noy, 2009; Halliday, 2006; Horwich, 2000; Selcuk \& Yeldan, 2001).

The first strand may not be directly related to our investigation as it focuses on the reaction of households in the mostly rural Least Developed Countries (LDCs) to changes in rainfall and draughts. The second strand is more directly relevant to our work. However, Vietnam-a rapid industrializer in its early stage of development-has a high exposure to storm events, and these pose a different set of issues regarding disaster vulnerabilities and their aftermath. These storms, unlike geo-physical disasters (earthquakes, volcanic eruptions and the tsunamis they both may generate), are fairly frequent and expected. Vietnam's consistent exposure to disasters may generate different macroeconomic dynamics surrounding them when compared to countries that only experience infrequent but very large geo-physical events.

Our work on the Vietnamese economic vulnerability to natural disasters is different also since we avoid the difficulty of identifying the impact of a single event in a case study. However, our findings may be specific to Vietnam. General conclusions can only be reliably derived from a meta-analysis relying on a larger number of similar empirical works.

As far as we know, there are only very few papers that examine any macroeconomic facet of natural disasters using a multiple-events framework. These are briefly discussed below, though none of them attempts to answer the questions we pursue hereafter for the case of a single developing country such as Vietnam. The first recent attempt to empirically describe macro-aspects of natural disasters is Albala-Bertrand (1993). In this seminal monograph, Albala-Bertrand develops an analytical model of disaster occurrence and reaction and collects data on a set of disaster events: 28 disasters in 26 countries during 1960-1979. Based on before-after statistical analysis, he finds that GDP increases, inflation does not change, capital formation increases, agricultural and construction output increase, the twin deficits increase (the trade deficit sharply), reserves increase, but no discernible impact on the exchange rate is observed. The patterns of onset and recovery observable in this dataset are then described with a special emphasis on the political economy aspects of the events themselves. Rasmussen (2004) conducts a similar tabulation of the data for Caribbean Islands. Tol and Leek (1999) survey the literature as far back as the 1960s, and argue that the positive effect on GDP can readily be explained since disasters destroy the capital stock, while the GDP measure focuses on the flow of new production.

Skidmore and Toya (2002) and Noy and Nualsri (2007) examine the long-run impact of natural disasters on growth. The former use the frequency of natural disasters for the 1960-1990 period for each country normalized by land size in a crosssectional dataset while the latter use a panel of country-5-year observations as in the extensive literature that followed the work by Barro (1997). Both these papers investigate the long-run trends (averaged across countries) in contrast with our aim of describing the short-run dynamics of the macroeconomy following disasters for a specific developing country. ${ }^{5}$ Long-run analysis raises questions of endogeneity in disaster impact that are, to a large extent, not relevant for the short-run (we confirm this later).

We are aware of only two papers that have attempted to investigate the short-run dynamics of output following disasters in a broad cross-country dataset, and no papers that have attempted to do that for a specific country using national or subnational regional/sectoral data. Raddatz (2007) investigates the external sources of short-run output volatility in low income developing countries. Using a VAR empirical methodology, the paper analyses the contribution of various external shocks, natural disasters among them, in explaining output fluctuations. Raddatz (2007) concludes that natural disasters do have an adverse short-run impact on output dynamics.

Noy (2009) also finds an adverse short-run effect and describes some of the structural and institutional details that make this negative effect worse. In particular, he concludes that countries with a higher literacy rate, better institutions, higher per capita income, higher degree of openness to trade, higher levels of government spending, more foreign exchange reserves, and higher levels of domestic credit, but with less-open capital accounts are better able to withstand the initial disaster shock and prevent further spillovers. Given these findings, Vietnam is an especially interesting case with its low per capita income but high literacy rate, rapidly increasing trade openness, and a high degree of government economic involvement.

Several papers investigate the institutional and structural determinants of initial disaster costs (Anbarci, Escaleras, \& Register, 2005; Kahn, 2004; Raschky, 2008; Skidmore \& Toya, 2007) or of the subsequent impact on the economy (Cavallo, Galiani, Noy, \& Pantano, 2009; Noy, 2009). To the best of our knowledge, however, no work has attempted to neither address any of these issues nor answer any of the questions we pose using data from the sub-national level or with a focus on a particular country.

\footnotetext{
5 Skidmore and Toya (2002) and Noy and Nualsri (2007) also reach diametrically opposing conclusions with the former identifying expansionary and the latter contractionary disaster effects.
} 


\subsection{Other macroeconomic impacts of disasters}

As in most previous research, we focus here on the impact of disasters on growth and production. However, other impacts of disasters have also been under-investigated. For example, when the disasters are likely to generate significant interregional fiscal transfers, a more precise account of their fiscal impact is necessary. On the expenditure side, the disaster reconstruction costs to the public may be very different than the original magnitude of destruction of capital that occurred. The impact of disasters on tax and other revenue sources has also seldom been quantitatively examined. A cross-country investigation of these effects, as in Noy and Nualsri (2008), yields some useful predictions, but to a large extent, the disasters' impacts on revenue and spending depend on the country-specific macroeconomic dynamics occurring following the disaster shock, and the unique structure of revenue sources (income taxes, consumption taxes, custom dues, etc.) and expenditures. Another motivation to estimate the fiscal cost is to better enable governments to directly insure against disaster losses, indirectly through the issuance of catastrophic bonds (CAT bonds), or through precautionary saving. The only attempt we know of estimating the likely fiscal insurance needs of a government has been calculated for Belize (Borensztein, Cavallo, \& Valenzuela, 2008); though whether these estimates for Belize apply to Vietnam, for example, is an unexplored question.

\section{Data and methodology}

\subsection{Data}

The data on natural disasters and their impacts for 64 provinces in Vietnam are available from the OFDA/CRED International Disaster Database for the period from 1953 to 2008 . However, data on output values for primary industry (including agricultural, forestry, and fishery) are only available for the period from 1995 to 2006 . Hence, this is our estimation period. There are several provinces that were merged together before 1995 and then split again sometime after 1995, so we have to sum up data for these provinces and thus have data for 61 provinces to estimate.

As in Noy (2009), we use three reported measures of the magnitude of the disaster to form the damage measures (DM): (1) The number of people killed (KIL); (2) the number of people affected $(A F F)$; and (3) the amount of direct damage (DAM). We weigh our measure based on the month in which the disaster occurred. The measure we use (DMS) is calculated based on the three alternative damage measures $(D M)$ and the onset month $(O M)$ :

$D M S=\frac{D M(12-O M)}{12}$

Data for KIL and AFF are then divided by the provincial population to obtain per capita measure, KILP and AFFP. Data for DAM are divided by provincial output values to obtain the ratio of damage to output, DAMO.

Since disaster damages affect the following-year output in reverse order, for example, disasters occurred in January of a particular year will probably have the least effect on the following-year output whereas those occurred in December will most likely have the most short-run effect, we weigh the lagged values of disaster measures (DMSL) using the onset month as the weight:

$D M S L=\frac{D M \times O M}{12}$

Provincial data for other variables, including output values, domestic trade, school-enrollments as a proxy for education, freight traffic as a proxy for infrastructure, and numbers of medical staffs as a proxy for health care, are available from the Vietnam's Statistical Yearbooks (VSY) by the General Statistics Office of Vietnam (GSOV) from 1995 to 2006 . To construct the variable output (OUT) we sum up the output values for primary sector and the output values for the secondary sector (called "industry" sector in VSY), which includes mining and quarrying, manufacturing, electricity, water, and gas supply. These output values are in 1994 constant Vietnamese Dong. Data on investment and actual foreign investment are only available for economic sectors as shown in $\mathrm{Vu}$ (2008). Since they are not available for individual provinces, they are accounted for by our time-fixed effects, and we do not use these in our estimations.

The domestic trade values are in current Vietnamese Dong. We convert them to the 1994 constant price using the consumer price index. For school-enrollments, we sum up primary, secondary, vocational, and technical schools and college enrollments and divide them by population to obtain a proxy for education. We also divide the number of medical staff by population to obtain proxies for available health care. Data on domestic trade are divided by the output values and are expressed a percentage of output. Data on freight traffic is also divided by population to obtain a proxy for infrastructure. Information about the variables and their sources is summarized in Appendix A. The tables in Appendix B provide more detailed information about the disaster variables and their temporal distribution.

\subsection{Methodology}

We estimate the equation

$Y_{i, t}=\alpha_{i}^{1}+\alpha_{t}^{2}+\beta Y_{i, t-1}+\gamma D M S_{i, t}+\chi D M S L_{i, t-1}+\phi X_{i, t-1}+\varepsilon_{i, t}$ 
Table 2

Effects of disasters on output (dependent variable: annual output).

\begin{tabular}{|c|c|c|c|c|c|c|}
\hline \multirow[t]{2}{*}{ Variable } & \multicolumn{2}{|l|}{ (1) } & \multicolumn{2}{|l|}{$(2)$} & \multicolumn{2}{|l|}{ (3) } \\
\hline & (5.1a) & (5.1b) & $(5.2 \mathrm{a})$ & (5.2b) & (5.3a) & $(5.3 b)$ \\
\hline OUTL & $\begin{array}{l}.115^{* * *} \\
(.000)\end{array}$ & & $\begin{array}{l}.103^{* * *} \\
(.004)\end{array}$ & & $\begin{array}{l}.111^{* * *} \\
(.003)\end{array}$ & \\
\hline KILP & $\begin{array}{r}-131.2^{* * *} \\
(.007)\end{array}$ & $\begin{array}{r}-235.6^{* * *} \\
(.006)\end{array}$ & & & & \\
\hline KILPL & $\begin{array}{r}-104.4 \\
(.376)\end{array}$ & & & & & \\
\hline AFFP & & & $\begin{array}{r}-15.24^{* * *} \\
(.015)\end{array}$ & $\begin{array}{r}-17.69^{* *} \\
(.021)\end{array}$ & & \\
\hline AFFPL & & & $\begin{array}{r}-2.45 \\
(.107)\end{array}$ & & & \\
\hline DAMO & & & & & $\begin{array}{l}.022 \\
(.527)\end{array}$ & $\begin{array}{l}.025 \\
(.447)\end{array}$ \\
\hline DAMOL & & & & & $\begin{array}{l}.003 \\
(.354)\end{array}$ & \\
\hline INFRA & $\begin{array}{l}138.5^{* *} \\
(.032)\end{array}$ & & $\begin{array}{l}12.98 \\
(.476)\end{array}$ & & $\begin{array}{l}14.2^{* * *} \\
(.021)\end{array}$ & \\
\hline TRADE & $\begin{array}{c}14.25^{* *} \\
(.008)\end{array}$ & & $\begin{array}{r}16.35^{* *} \\
(.045)\end{array}$ & & $\begin{array}{l}9.54^{* *} \\
(.047)\end{array}$ & \\
\hline EDUC & $\begin{array}{l}2.191^{* * *} \\
(.041)\end{array}$ & & $\begin{array}{c}1.692^{* * * *} \\
(.009)\end{array}$ & & $\begin{array}{l}3.164^{* *} \\
(.036)\end{array}$ & \\
\hline HEALTH & $\begin{array}{l}2.812 \\
(.142)\end{array}$ & & $\begin{array}{l}3.132^{* *} \\
(.028)\end{array}$ & & $\begin{array}{l}2.21^{* *} \\
(.041)\end{array}$ & \\
\hline Observations & 546 & & 546 & & 546 & \\
\hline$p$-Value for $F$-test & .000 & & .000 & & .000 & \\
\hline$p$-Value for AR(1) & .243 & & .329 & & .392 & \\
\hline$p$-Value for $\operatorname{AR}(2)$ & .671 & & .429 & & .725 & \\
\hline Chi' ${ }^{2}$-Sargan & .591 & & .690 & & .459 & \\
\hline Chi $^{2}$-Hansen & .286 & & .697 & & .742 & \\
\hline
\end{tabular}

Note: The same as in Table 2.

** Significant level at 5 percent with $p$-values in parentheses.

*** Significant level at 1 percent with $p$-values in parentheses.

where $Y$ is alternatively annual output or the annual output growth rate, $i$ is a provincial index, and $t$ the time index. $\alpha_{i}^{1}$ and $\alpha_{t}^{2}$ are the region and time-fixed effects, $D M S_{i, t}$ is our measure for disaster magnitude, estimated separately for each type of damage (either KILP, AFFP, or DAMO), and $X_{i, t-1}$ are the lagged control variables as described in the previous section.

We employ the Blundell-Bond System General Method of Moments (GMM) procedure as described in Blundell and Bond (1998) and Bond (2002) to control for the presence of lagged dependent variable in the estimated panel. The Blundell-Bond procedure is a refined application of the Arellano and Bond (1991) and the Arellano and Bover (1995) procedures. Arellano and Bond (1991) developed the difference-GMM estimator for dynamic panels. The method takes into account that lagged dependent variables are predetermined but not exogenous: although they are independent of current disturbances, they might be influenced by past ones. Differencing the lagged dependent variables or taking deviations from the mean will eliminate the fixed effects. Nonetheless, the difference-GMM produces biased coefficient estimates and unreliable tests when an endogenous variable is close to a random walk. In this case, past values provide little information about future changes, so the untransformed lags are weak instruments for transformed variables.

To solve this problem, Blundell and Bond (1998) develop a modified procedure introduced in Arellano and Bover (1995). In this approach, they add the difference of the instrumental variable (IVs) to make them exogenous to the fixed effects. The Blundell-Bond (1998) system approach effectively controls for autocorrelation and heteroskedasticity, provides consistent coefficient estimates, and performs more reliable Arellano-Bond tests for autocorrelations and Sargent test for overidentifying restrictions than the original Arellano-Bond (1991).

We employ the two-step estimation procedure for small samples. For the number of lags to include, we use the Akaike Information Criterion (AIC) and Schwarz Bayesian Information Criterion (BIC); for both, only the first lagged value of each variable is significant. We also carry out the modified Hausman endogeneity test to pinpoint the endogenous variables that need instrumental variables in the procedure for each regression (results available upon request).

The system-GMM methodology we use is intended to overcome the problems posed by the inclusion of a lagged dependent variable in a panel set-up with some endogeneity. Yet, in order to derive causal inferences on the effect of the disaster variables on our macroeconomic measures of interest (mainly GDP growth), we generally require further assumptions. 
Table 3

Effects of disasters on output growth. Model without initial output (dependent variable: annual output growth).

\begin{tabular}{|c|c|c|c|c|c|c|}
\hline \multirow[t]{2}{*}{ Variable } & \multicolumn{2}{|l|}{ (1) } & \multicolumn{2}{|l|}{$(2)$} & \multicolumn{2}{|l|}{ (3) } \\
\hline & (6.1a) & (6.1b) & $(6.2 \mathrm{a})$ & (6.2b) & (6.3a) & (6.3b) \\
\hline OUTGL & $\begin{array}{l}.0533^{* *} \\
(.045)\end{array}$ & & $\begin{array}{l}.0665^{* * *} \\
(.008)\end{array}$ & & $\begin{array}{l}.0867^{* * *} \\
(.004)\end{array}$ & \\
\hline KILP & $\begin{array}{r}-.725 \\
(.328)\end{array}$ & $\begin{array}{r}-.112 \\
(.463)\end{array}$ & & & & \\
\hline KILPL & $\begin{array}{l}.613 \\
(.657)\end{array}$ & & & & & \\
\hline$A F F P$ & & & $\begin{array}{l}.0031 \\
(.687)\end{array}$ & $\begin{array}{r}-.0055 \\
(.563)\end{array}$ & & \\
\hline AFFPL & & & $\begin{array}{r}-.0086 \\
(.463)\end{array}$ & & & \\
\hline DAMO & & & & & $\begin{array}{l}.0005^{* *} \\
(.031)\end{array}$ & $\begin{array}{l}.0003^{* *} \\
(.042)\end{array}$ \\
\hline DAMOL & & & & & $\begin{array}{r}-.0002 \\
(.435)\end{array}$ & \\
\hline INFRA & $\begin{array}{l}.2243^{* *} \\
(.029)\end{array}$ & & $\begin{array}{l}.6648^{* *} \\
(.0254)\end{array}$ & & $\begin{array}{l}.207^{* *} \\
(.028)\end{array}$ & \\
\hline TRADE & $\begin{array}{l}.4692^{* *} \\
(.031)\end{array}$ & & $\begin{array}{l}.5281^{* *} \\
(.041)\end{array}$ & & $\begin{array}{l}.1546^{* *} \\
(.047)\end{array}$ & \\
\hline EDUC & $\begin{array}{l}.3342^{* * *} \\
(.009)\end{array}$ & & $\begin{array}{l}.3825^{* *} \\
(.045)\end{array}$ & & $\begin{array}{l}.4973^{* *} \\
(.035)\end{array}$ & \\
\hline HEALTH & $\begin{array}{l}.6504^{* *} \\
(.034)\end{array}$ & & $\begin{array}{l}.5625 \\
(.165)\end{array}$ & & $\begin{array}{l}.4102 \\
(.854)\end{array}$ & \\
\hline Observations & 486 & & 486 & & 486 & \\
\hline$p$-Value for $F$-test & .000 & & .000 & & .000 & \\
\hline$p$-Value for $\mathrm{AR}(1)$ & .143 & & .228 & & .213 & \\
\hline$p$-Value for $\mathrm{AR}(2)$ & .798 & & .675 & & .786 & \\
\hline $\mathrm{Chi}^{2}$-Sagan test & .465 & & .576 & & .755 & \\
\hline $\mathrm{Chi}^{2}$-Hansen test & .453 & & .435 & & .645 & \\
\hline
\end{tabular}

Note: The associated $p$-values for coefficients are in parentheses. *Significant level at 10 percent with $p$-values in parentheses. The $p$-value for AR(1) and $p$ value for $\operatorname{AR}(2)$ are from Arellano-Bond test for $\operatorname{AR}(1)$ and $\operatorname{AR}(2)$ in first differences and second differences, respectively.

** Significant level at 5 percent with $p$-values in parentheses.

*** Significant level at 1 percent with $p$-values in parentheses.

Since there may be plausible reasons why the previous growth experience may have some impact on these disaster measures, we conduct Granger-causality tests. We regress the disaster variable on its own lags, output lags, and other variables, and test the significance of the output lags. The $t$-statistics for the output (at any lag structure) and the $F$-statistic for joint significance all indicate that output does not Granger-cause the disaster magnitude measures. Our assumption of (weak) exogeneity of the disaster measures appears to be justified. This assumption is also adopted by the four other papers that use a disaster measure as an independent variable, albeit in very different specifications and with different datasets (Noy, 2009; Raddatz, 2007; Ramcharan, 2007; Skidmore \& Toya, 2002).

\section{Estimation results}

Table 2 shows regression results for the model with dependent variable as annual output. The independent variables include lagged output (the dynamic panel structure) and current and lagged values of damage-measure variables (lags are all with the suffix $L$ ). Since we use lagged and contemporaneous disaster variables, a special interpretation is needed. The next column after each specification lists the sum of the two disaster coefficient and provides the $p$-value of this sum. Our estimates for the total effect of a disaster, however, can be interpreted as a lower bound, since in calculating the total impact of a disaster we ignore the dynamic panel component (the lagged dependent variable on the RHS).

The results of the original coefficient estimates for KILP, AFFP, and DAMO, are reported in Columns (2.1a), (2.2a), and (2.3a) respectively, whereas the sums of the two coefficients for each variable KILP, AFFP, and DAMO are report in all the corresponding (b) columns, respectively. From this table, the impacts of the number of people killed (KILP) and the number of people affected $(A F F)$ on annual output are negative whereas the impact of the amount of direct damages (DAMO) on annual output is not significantly different from zero. By these results, a large disaster will also result in large economic dislocation: for a one percentage point increase in the ratio of people killed to population, there is a decrease of output by 235.6 trillion Dong.

Next, we estimate the model with dependent variable as annual output growth, we first regress annual output growth on each of the variable for disaster damage: KILP, AFFP, DAMO, education, trade, and infrastructure. Table 3 reports the results. It shows that the impact of the number of people killed and the number of people affected on annual output growth are not statistically significant. Nevertheless, the impact of the amount of direct damage is positive and significant; albeit not very 
Table 4

Effects of disasters on output growth. Model with initial output (dependent variable: annual output growth).

\begin{tabular}{|c|c|c|c|c|c|c|}
\hline \multirow[t]{2}{*}{ Variable } & \multicolumn{2}{|l|}{ (1) } & \multicolumn{2}{|l|}{ (2) } & \multicolumn{2}{|l|}{ (3) } \\
\hline & $(7.1 \mathrm{a})$ & (7.1b) & $(7.2 \mathrm{a})$ & $(7.2 b)$ & $(7.3 a)$ & (7.3b) \\
\hline OUTGL & $\begin{array}{l}.0561^{* *} \\
(.040)\end{array}$ & & $\begin{array}{l}.0362^{* *} \\
(.024)\end{array}$ & & $\begin{array}{l}.065^{* * * *} \\
(.009)\end{array}$ & \\
\hline KILP & $\begin{array}{r}-.467 \\
(.647)\end{array}$ & $\begin{array}{r}-.102 \\
(.463)\end{array}$ & & & & \\
\hline KILPL & $\begin{array}{l}.365 \\
(.153)\end{array}$ & & & & & \\
\hline$A F F P$ & & & $\begin{array}{r}-.0034 \\
(.681)\end{array}$ & $\begin{array}{l}.044 \\
(.456)\end{array}$ & & \\
\hline AFFPL & & & $\begin{array}{l}.0078 \\
(.435)\end{array}$ & & & \\
\hline DAMO & & & & & $\begin{array}{l}.0006^{* *} \\
(.024)\end{array}$ & $\begin{array}{l}.0004^{* *} \\
(.029)\end{array}$ \\
\hline DAMOL & & & & & $\begin{array}{c}-.0002^{* *} \\
(.035)\end{array}$ & \\
\hline INFRA & $\begin{array}{l}.5942^{* *} \\
(.032)\end{array}$ & & $\begin{array}{l}.4245^{* *} \\
(.029)\end{array}$ & & $\begin{array}{l}.3647^{* *} \\
(.035)\end{array}$ & \\
\hline TRADE & $\begin{array}{l}.6546^{* *} \\
(.045)\end{array}$ & & $\begin{array}{l}.4235 \\
(.325)\end{array}$ & & $\begin{array}{l}.4571^{* *} \\
(.043)\end{array}$ & \\
\hline EDUC & $\begin{array}{l}.4521^{* *} \\
(.034)\end{array}$ & & $\begin{array}{l}.4346^{* *} \\
(.025)\end{array}$ & & $\begin{array}{l}.6924^{* * *} \\
(.015)\end{array}$ & \\
\hline HEALTH & $\begin{array}{l}.1228^{* *} \\
(.028)\end{array}$ & & $\begin{array}{l}.1359^{* *} \\
(.032)\end{array}$ & & $\begin{array}{l}.1028^{* *} \\
(.044)\end{array}$ & \\
\hline INOUT & $\begin{array}{c}-.0576^{* *} \\
(.046)\end{array}$ & & $\begin{array}{c}-.1486^{* * *} \\
(.007)\end{array}$ & & $\begin{array}{c}-.0243^{* *} \\
(.037)\end{array}$ & \\
\hline Observations & 482 & & 482 & & 482 & \\
\hline$p$-Value for $F$-test & .000 & & .000 & & .000 & \\
\hline$p$-Value for $\mathrm{AR}(1)$ & .114 & & .142 & & .124 & \\
\hline$p$-Value for $\operatorname{AR}(2)$ & .539 & & .768 & & .647 & \\
\hline Chi ${ }^{2}$-Sargan test & .758 & & .698 & & .912 & \\
\hline Chi' ${ }^{2}$-Hasen test & .576 & & .576 & & .605 & \\
\hline
\end{tabular}

Note: The same as in Table 2.

large. Specifically, summing up DAMO and DANMOL gives us 0.0003 , that is, for one percentage point increase in direct damage (\% of output), there is an increase of output growth by $0.03 \%$, regardless of the initial output level. These imply that the negative economic effects of natural disasters in Vietnam, if there are any, are short lived. This may further represent the resiliency of a rapidly developing economy. ${ }^{6}$

Since many growth models add initial output value as an independent variable, we also repeat the exercise for the model in Table 3 with initial output values as an additional control variable. Table 4 reports the results. The signs and significances of the disaster damages on output growths are similar to the previously reported results in Table 3. For example, for a one percentage point increase in the ratio of direct damage to output there is an increase of output growth by $0.04 \%$.

Because the impact of the amount of direct damage on output growth is positive and significant, we want to see if regions with higher frequencies of disasters enjoy more output growth than regions with low frequencies of disasters. We use the Red River Delta region, which has the lowest frequency of disasters, as the base group. Although floods occur frequently there, only the ones with significant damages are reported by the OFDA/CRED International Disaster Database. Hence, this region still has the lowest frequency among all regions in Vietnam. We generate seven slope dummies for the other seven regions and regress output growth on the amount of direct damage with all control variables added, including the initial output values. Table 5 reports only the results for the benchmark variables (other results are available upon request). The base group takes on the coefficient of the direct damage (DAMO), which shows the effect of DAMO on the output growth of the Red River Delta region.

The differences in coefficients of other groups relative to the base group are reported in Column 5.1. A positive sign implies a region enjoys higher output growth than the base region and vice versa. Coefficients of the other groups are calculated by sum up coefficient of each group to the coefficient of the base group. Tests are performed to see if they are

\footnotetext{
${ }^{6}$ This results regarding the impact of different disaster measures, and especially the potentially positive impact, is in line with the cross-country comparative finding, reported in Noy (2009), that countries that are able to mobilize resources for disaster reconstruction more quickly generally enjoy less adverse outcomes following disasters. A centralized economy, with an authoritarian government, large saving rates, and little openness in the capital account, is clearly able to generate more resources for reconstruction.
} 
Table 5

Regional effects of disasters on output growth (dependent variable: annual output growth).

\begin{tabular}{|c|c|c|c|}
\hline Variable & 8.1 & 8.2 & 8.3 \\
\hline \multirow[t]{2}{*}{ DAMO } & $.124^{* *}$ & & $.181^{* *}$ \\
\hline & $(.042)$ & & $(.032)$ \\
\hline \multirow[t]{2}{*}{ DAMOL } & $.057^{* *}$ & & \\
\hline & $(.028)$ & & \\
\hline \multirow[t]{2}{*}{ Northeast area } & -.009 & $.115^{* *}$ & $.187^{* *}$ \\
\hline & $(.486)$ & $(.041)$ & $(.045)$ \\
\hline \multirow{2}{*}{ Northeast area lag } & .015 & $.072^{* *}$ & \\
\hline & $(.362)$ & $(.009)$ & \\
\hline \multirow[t]{2}{*}{ Northwest area } & $-.113^{* *}$ & .011 & .045 \\
\hline & (.039) & $(.647)$ & $(.574)$ \\
\hline \multirow[t]{2}{*}{ Northwest area lag } & -.023 & .034 & \\
\hline & $(.364)$ & $(.436)$ & \\
\hline \multirow[t]{2}{*}{ North Central Coast } & .009 & $.133^{* *}$ & $1.73^{* *}$ \\
\hline & $(.435)$ & $(.029)$ & $(.046)$ \\
\hline \multirow[t]{2}{*}{ North Central Coast lag } & -.017 & $.040^{*}$ & \\
\hline & $(.475)$ & $(.092)$ & \\
\hline \multirow[t]{2}{*}{ South Central Coast } & -.022 & $.102^{* *}$ & $.179^{* *}$ \\
\hline & $(.329)$ & $(.034)$ & $(.041)$ \\
\hline \multirow[t]{2}{*}{ South Central Coast lag } & .020 & .077 & \\
\hline & $(.589)$ & $(.243)$ & \\
\hline \multirow[t]{2}{*}{ Central highlands } & $-.113^{* *}$ & .011 & .016 \\
\hline & $(.032)$ & $(.529)$ & $(.387)$ \\
\hline \multirow[t]{2}{*}{ Central highlands } & $-.052^{* *}$ & .005 & \\
\hline & $(.031)$ & $(.564)$ & \\
\hline \multirow[t]{2}{*}{ Southeast area } & $.044^{* *}$ & $.168^{* *}$ & $.257^{* *}$ \\
\hline & $(.041)$ & $(.031)$ & $(.026)$ \\
\hline \multirow{2}{*}{ Southeast area lag } & $.032^{* *}$ & $.089^{* * *}$ & \\
\hline & $(.036)$ & $(.007)$ & \\
\hline \multirow[t]{2}{*}{ Mekong River Delta } & .015 & $.129 * *$ & $.170^{* *}$ \\
\hline & $(.634)$ & $(.025)$ & $(.033)$ \\
\hline \multirow[t]{2}{*}{ Mekong River Delta lag } & -.016 & $.041^{* *}$ & \\
\hline & $(.473)$ & $(.041)$ & \\
\hline Observations & 482 & 482 & 482 \\
\hline$p$-Value for $F$-test & .000 & .000 & .000 \\
\hline$p$-Value for $\mathrm{AR}(1)$ & .132 & .154 & .124 \\
\hline$p$-Value for $\operatorname{AR}(2)$ & .565 & .376 & .694 \\
\hline $\mathrm{Chi}^{2}$-Sargan test & .747 & .657 & .579 \\
\hline $\mathrm{Chi}^{2}$-Hasen test & .645 & .584 & .486 \\
\hline
\end{tabular}

Note: The same as in Table 2.

significantly greater or smaller than zero. Column 5.2 reports these calculated coefficient and $p$-values for their significances. Column 5.3 then reports sum of the lagged value and the current value for all regions and their respective p-values. By subtracting, for example, the coefficient of the Red River Delta region from that of the Southeast region gives us 0.076 ; this implies that the latter enjoys a $.078 \%$ higher growth rate of output than the former following a similar disaster.

The results show that most of the regions with higher frequencies of disasters do not enjoy higher output growth than the base region; though given the positive and statistically significant coefficient for the base region that does not mean that the other regions do not exhibit the same investment-producing destruction dynamics. Nevertheless, the effect of DAMO on output growth in the two least developed regions, the Northwest and the Central Highlands, is not statistically different from zero. Only the Southeast, which ranks fourth in high frequency and which has a higher level of development than all the other regions, has a coefficient that is significantly greater than that of the base region. This finding provides tentative support for the hypothesis that regions that have more access to reconstruction funds will grow faster following a disaster (Noy, 2009); and also appears to support the observation that only regions with high levels of development can enjoy capital upgrading after the occurrence of natural disasters (Cuaresma et al., 2008).

\section{Caveats and conclusions}

Using provincial data for primary and secondary industries in Vietnam, this paper estimated the impact of disasters on the macroeconomy. Our results show that more lethal disasters, in terms of lives lost and lives affected, result in lower output growth but that more costly disasters (in terms of destroyed capital) actually appear to boost the economy in the short-run. This result is consistent with the creative destruction hypothesis that we outlined earlier. We find further support for this hypothesis by examining the differing macroeconomic impacts of disasters in different 
geographical regions within the country. These differences appear to be determined by the degree of access to reconstruction funds both from the private sector and from the central government, where richer and less remote regions exhibit faster growth following a disaster.

Like any empirical research, better data has the potential of shedding more light on the results we find and on the channels of transmission we speculate about. In particular, the lack of provincial data on investment may be hindering a precise identification of the channels of transmission. It is, for example, possible that regions that have more access to foreign knowledge (through FDI) are more resilient, or that the channel of transmission we identify is actually not related to additional investment but rather to the necessity to re-build inventories. Whenever data on these variables become available, for Vietnam, or for other economies in similar circumstances, new estimations will be called for.

\section{Appendix A}

See Table A1.

\section{Appendix B}

See Tables B.1a and B.1b.

Table A1

Data sources.

\begin{tabular}{lll}
\hline Variable & Definition & Source \\
\hline DAMO & Damage from disaster as \% of output & EM-DAT $^{\mathrm{a}}$ and VSY \\
AFFP & Number of people affected by disaster \% of population) & EM-DAT and VSY $^{\mathrm{b}}$ \\
KILP & Number of people killed by disaster (\% of population) & EM-DAT and VSY \\
OUT & Output values (trillion 1994 Dong) & VSY \\
OUTG & Growth of output & VSY \\
INOUT & Initial output values & VSY \\
INFRA & Freight traffic as infrastructure (million km per person) & VSY \\
TRADE & Domestic trade (\% of output) & VSY \\
EDUC & School enrollment rate (\% of population) & VSY \\
HEALTH & Health care (number of medical staff per person) & VSY \\
\hline
\end{tabular}

${ }^{a}$ The OFDA/CRED International Disaster Database at www.em-dat.net, Université Catholique Louvain.

b Vietnam's Statistical Yearbooks, General Statistics Office of Vietnam, 1995-2006.

Table B.1a

Average numbers of disasters per month: January through June.

\begin{tabular}{lllllll}
\hline Region & January & February & March & April & May & June \\
\hline Red River Delta & 0.0185 & 0.0370 & 0.0555 & 0.0741 & 0.1111 & 0.0925 \\
Northeast area & 0.0741 & 0.0555 & 0.0925 & 0.0185 & 0.1296 \\
Northwest area & 0.0925 & 0.0741 & 0.0741 & 0.0555 & 0.0370 \\
North Central Coast & 0.0555 & 0.1111 & 0.0925 & 0.0741 & 0.1296 \\
South Central Coast & 0.0741 & 0.0555 & 0.1481 & 0.1667 & 0.2462 & 0.1296 \\
Central highlands & 0.0370 & 0.0741 & 0.1296 & 0.1111 & 0.1481 \\
Southeast area & 0.0370 & 0.0185 & 0.0741 & 0.925 & 0.1296 \\
Mekong River Delta & 0.0185 & 0.0370 & 0.0370 & 0.0555 & 0.0741 \\
\hline
\end{tabular}

Table B.1b

Average numbers of disasters per month: July through December.

\begin{tabular}{|c|c|c|c|c|c|c|}
\hline Region & July & August & September & October & November & December \\
\hline Red River Delta & 0.1296 & 0.1481 & 0.2222 & 0.2037 & 0.1825 & 0.1667 \\
\hline Northeast area & 0.1481 & 0.1667 & 0.1825 & 0.2407 & 0.2037 & 0.2222 \\
\hline Northwest area & 0.2222 & 0.1481 & 0.2407 & 0.2592 & 0.2407 & 0.1825 \\
\hline North Central Coast & 0.1667 & 0.2037 & 0.2777 & 0.2592 & 0.2407 & 0.2592 \\
\hline South Central Coast & 0.2777 & 0.3148 & 0.2462 & 0.3333 & 0.2592 & 0.2462 \\
\hline Central highlands & 0.2407 & 0.2037 & 0.2592 & 0.3142 & 0.2407 & 0.2037 \\
\hline Southeast area & 0.1481 & 0.1825 & 0.1667 & 0.2592 & 0.2407 & 0.1825 \\
\hline Mekong River Delta & 0.1481 & 0.2037 & 0.2592 & 0.3142 & 0.2592 & 0.2937 \\
\hline
\end{tabular}

Source: EM-DAT: The OFDA/CRED International Disaster Database at www.em-dat.net, Université Catholique de Louvain, Belgium. 


\section{References}

Albala-Bertrand, J. M. (1993). Political economy of large natural disasters. Oxford: Clarendon Press.

Anbarci, N., Escaleras, M., \& Register, C. A. (2005). Earthquake fatalities: The interaction of nature and political economy. Journal of Public Economics, 89, 19071933.

Arellano, M., \& Bond, S. (1991). Some tests of specification for panel data: Monte Carlo evidence and an application to employment equations. Review of Economic Studies, 58, 277-297.

Arellano, M., \& Bover, O. (1995). Another look at the instrumental variables estimation of error-components models. Journal of Econometrics, 68, 29-51.

Barro, R. (1997). Determinants of economic growth: A cross-country empirical study. Cambridge: MIT Press.

Benson, C., \& Clay, E. (2004). Understanding the economic and financial impacts of natural disasters. Disaster risk management series no. 4.

Blundell, R., \& Bond, S. (1998). Initial conditions and moment restrictions in dynamic panel data models. Journal of Econometrics, 87, $115-143$.

Bond, S. (2002). Dynamic panel data models: A guide to micro data methods and practice. CEMMAP working paper CWP09/, 02.

Borensztein, E., Cavallo, E., \& Valenzuela, P. (2008). Debt sustainability under catastrophic risk: The case for government budget insurance. IMF Working Paper 08/ 44.

Cavallo, E., Galiani, S., Noy, I., \& Pantano, J. (2009). Natural disasters and economic growth. Manuscript.

Cavallo, E., \& Noy, I. (2009). The economics of natural disasters - a survey. Inter-American Development Bank Working Paper \#124.

Coffman, M., \& Noy, I. (2009). Hurricane Iniki: Measuring the long-term economic impact of a natural disaster using synthetic control. University of Hawaii Economics Working Paper 09-05.

Cuaresma, J. C., Hlouskova, J., \& Obersteiner, M. (2008). Natural disasters as creative destruction? Evidence from developing countries. Economic Inquiry, 46(2), $214-226$

Halliday, T. (2006). Migration, risk and liquidity constraints in El Salvador. Economic Development and Cultural Change, 54(4), 893-925.

Horwich, G. (2000). Economic lessons of the Kobe earthquake. Economic Development and Cultural Change, 521-542.

Kahn, M. E. (2004). The death toll from natural disasters: The role of income, geography, and institutions. Review of Economics and Statistics, 87(2), 271-284.

Noy, I. (2009). The macroeconomic consequences of disasters. Journal of Development Economics, 88(2), $221-231$.

Noy, I., \& Nualsri, A. (2007). What do exogenous shocks tell us about growth theories? University of Hawaii Working Paper 07-28.

Noy, I., \& Nualsri, A. (2008). Fiscal storms: Public spending and revenues in the aftermath of natural disasters. University of Hawaii Working Paper 08-09.

Paxson, C. H. (1992). Using weather variability to estimate the response of savings to transitory income in Thailand. American Economic Review, 82(1), 15-33.

Raddatz, C. (2007). Are external shocks responsible for the instability of output in low-income countries? Journal of Development Economics, $84,155-187$.

Ramcharan, R. (2007). Does the exchange rate regime matter for real shocks? Evidence from windstorms and earthquakes. Journal of International Economics, 73, 31-47.

Raschky, P. A. (2008). Institutions and the losses from natural disasters. Natural Hazards Earth Systems Science, 8, 627-634.

Rasmussen, T. N. (2004). Macroeconomic implications of natural disasters in the Caribbean. IMF Working Paper 04/224.

Schumpeter, J. (2008). Capitalism, socialism and democracy. New York: Harper. [original publication in English, 1943].

Selcuk, F., \& Yeldan, E. (2001). On the macroeconomic impact of the August 1999 earthquake in Turkey: A first assessment. Applied Economics Letters, 8, 483-488.

Skidmore, M., \& Toya, H. (2002). Do natural disasters promote long-run growth? Economic Inquiry, 40(4), 664-687.

Skidmore, M., \& Toya, H. (2007). Economic development and the impacts of natural disasters. Economic Letters, 94, 20-25.

Tol, R., \& Leek, F. (1999). Economic analysis of natural disasters. In T. Downing, A. Olsthoorn, \& R. Tol (Eds.), Climate change and risk (pp. 308-327). London: Routledge.

Vu, T. B. (2008). Foreign direct investment and endogenous growth in Vietnam. Applied Economics, 40(9), 1165-1173. 